\title{
The Water Masses and Circulation at the Amery Ice Shelf
}

\author{
Hongxia Chen ${ }^{1,2}$, Lina Lin ${ }^{1,2}$, Yuansheng $\mathrm{Li}^{3}$, Mike Craven ${ }^{4}$ \\ ${ }^{1}$ First Institute of Oceanography State Oceanic Administration, Qingdao, China \\ ${ }^{2}$ Key laboratory of Marine Science and Numerical Modeling, State Administration, Qingdao, China \\ ${ }^{3}$ Polar Research Institute of China, Shanghai, China \\ ${ }^{4}$ Antarctic ACE-CRC and Australian Antarctic Division, Hobart, Australia \\ Email: chenhx@fio.org.cn
}

Received 4 March 2016; accepted 24 April 2016; published 29 April 2016

Copyright (C) 2016 by authors and OALib.

This work is licensed under the Creative Commons Attribution International License (CC BY).

http://creativecommons.org/licenses/by/4.0/

c) (i) Open Access

\begin{abstract}
AM06 is a site upstream about $130 \mathrm{~km}$ of the calving front, where it was believed in a region with weak accreted marine ice near the $500 \mathrm{~m}$ ice shelf draft line west of Gillock Island. This borehole was melted through the shelf in January 2010, to access the ocean cavity. Based on Microcats and ADCP data during 2010 and 2011, the motion of AIS is discussed, water masses and circulation at the Amery Ice Shelf are studied for the first time. Salinity and temperature data in the cavity at AM06 show a strong seasonal cycle as a result of HSSW inflow and ISW outflow. Other preliminary results such as circulation and seasonal cycle of the water masses and identification of the basal melting/freezing regime of AM06 are also reported.
\end{abstract}

\section{Keywords}

Amery Ice Shelf, Prydz Bay, Water Masses, Circulation

Subject Areas: Oceanology

\section{Introduction}

The Lambert Glacier, draining 16 percent of the East Antarctic ice area, feeds the Amery Ice Shelf (AIS), which is the third largest embayed shelf in Antarctica, and the largest entirely within East Antarctica [1]. Ocean water penetrates over $550 \mathrm{~km}$ under the AIS, which thins as it flows towards the Prydz Bay, and losses mass by calving of icebergs at its face. It is also diminished by melting where it meets ocean water underneath, an interaction with potential implications for the flow of the glaciers. Supercooled water flows out from under the AIS into Prydz Bay, where it interacts with ocean water and ice to influence Prydz Bay circulation and thus the local ecosystem. It also contributes to the formation of dense Antarctic Bottom Water which ventilates the deep ocean 
[2]-[4].

The AIS has been the focus of considerable investigation by the Australian National Antarctic Research Expedition (ANARE) since as early as the mid 1950s, although only in the past decade has the importance of iceocean interaction beneath the shelf become fully apparent [5]. The importance of the processes of ice shelfocean interaction to both the Antarctic mass budget and the modification of the characteristics of the ocean, and the sensitivity of these processes to changes of ocean temperature and circulation near Antarctica led to the establishment of a project of "Amery Ice Shelf Ocean Research (AMISOR)". This multidisciplinary project aims to quantify the processes occurring under the shelf, especially the heat and freshwater exchanges between the ocean and the AIS, and determine the implications of this interaction for the discharge of grounded ice and water mass modification.

AMISOR is comprised of two field work components, the ongoing ice shelf based instrumentation deployments and the completed ship-based CTD and mooring work [6]. The former includes hot-water drilling through the AIS, oceanographic measurements in the underlying cavity, glaciological measurements of the ice shelf velocity, strain and thickness. Oceanographic aims of AIS include primarily: describing the distribution of the meltwater from the Amery Ice Shelf cavity, estimating the thermohaline circulation, estimating the freshwater flux from underneath the ice shelf and the heat flux into the ice shelf, including the seasonal cycle.

Based on AMISOR borehole in situ data, Craven et al. first documented the intrusion of relatively warm waters beneath the AIS from observations collected at the borehole site AM02, a $200 \mathrm{~m}$ thick layer of marine ice underlay the meteoric ice and an increase in salinity with depth at site AM01 [7]. With two boreholes drilled through the eastern marine ice band at two locations $70 \mathrm{~km}$ apart on the same flowline (AM01 and AM04), Mike Craven et al. determined an average accretion rate of marine ice, and inferred a similar average rate upstream, estimated an average closure rate between the borehole sites [8].

With AMISOR in situ data at borehole AM01, Herraiz-Borreguero et al. documented the seasonal variability of the AIS-ocean interaction beneath the marine ice layer during 2002 [9]. Herraiz-Borreguero et al. expanded on the results presented in Craven et al. and, especially documented the spatial variability and seasonal inflow of modified Circumpolar Deep Water (mCDW), and described the circulation and seasonal cycle of the water masses observed at site AM02 [7] [10].

Based on field work occupied by CHINARE and international cooperations such as with ANARE, especially during the fourth International Polar Year (IPY4), the AIS study of Chinese scholars mainly focused on ice shelf structure and bottom shape, ice shelf movement, oceanography under the ice shelf. Based on radar detection techniques, Deng and Sun [11] revealed the basic internal structure characteristics of Amery Ice Shelf. With GPS data on the Amery Ice Shelf, Zhang et al. obtained the flow velocity and direction of the front of the ice shelf [12], and Zhang et al. determined dynamic parameters and extracted tidal signals of AIS [13]. With LADCP and CTD data, Chen et al. analyzed current profiles structure in sea area of the front of AIS [14]. Wen et al. evaluated the basal melting and freezing under the Amery Ice Shelf using in situ datasets along with a column-averaged ice density model [15].

AM06 $\left(71^{\circ} 21^{\prime} \mathrm{E}, 70^{\circ} 15^{\prime} \mathrm{S}\right)$ is a site near the $500 \mathrm{~m}$ ice shelf draft line west of Gillock Island, and upstream about $130 \mathrm{~km}$ of the calving front, roughly $80 \mathrm{~km}$ south of AM02. Fricker et al. believed it was in a region with weak accreted marine ice [16], while in the model result of Williams et al., this site located in a anti-clockwise circulation area with melting rate about $0.2 \mathrm{~m} \cdot \mathrm{yr}^{-1}$ [17]. No direct evidence supported the viewpoint of Fricker et al. or Williams et al. at that time.

Since 1988, the Prydz Bay has been the focus of investigation by the Chinese National Antarctic Research Expedition (CHINARE), although the expedition focused on AIS and its front sea area began to be carried out since 2002. Next year, cooperated with ANARE AIS team, 3 members of CHINARE-20 participated in the Hot Water Drilling (HWD) field work for the first time at site AM01. Full CTD profiles data, water samples at different layer and bottom sediment sample were collected. Though the ANARE has begun long term mooring ever since 2001 at this site, the RDI $300 \mathrm{kHz}$ broadband Workhorse ADCP taken to AIS by Chinese members was deployed at AM06 several years later by ANARE.

Based on these data collected at AM06, this paper studied the motion of AIS, discussed water mass variability in terms of three periods, made the seasonal cycle of circulation at this site clear, and particularly documented the seasonal variability inflow of HSSW and outflow of ISW, identified the basal melting/freezing regime of AM06. 


\section{Data Collection}

During austral summer 2010, borehole at AM06 was melted through the shelf, to access the ocean cavity. Immediately after the hot water drilling and before the deployment of the mooring, a series of CTD profiles were obtained from the ocean water column using a Falmouth Scientific (FSI) microCTD. Ten isolated downward and upward profiles were successfully retrieved from the AM06 site in 3 days. Ever since January 7th 2010, a string of three Seabird SBE37IM Microcats and one RDI 300 kHz broadband Workhorse ADCP have been deployed through AMISOR borehole AM06 to collect long term oceanographic data including time series data of temperature, salinity, pressure, and current profiles. At this site, global positioning system (GPS) observations were made in January of 2010, 2011 respectively.

\subsection{GPS Records}

Garmin GPS was used to locate the accurate coordinate of AM06 in each field work season (Table 1). These GPS records are helpful to calculate the motion of AIS, to identify the magnetic declination, and to adjust the current direction measured by ADCP.

\subsection{CTD Profiles}

Temperature, salinity and pressure profiles data were collected from lowered and recovered FSI CTD in austral summer 2010, and these profiles give information about water column stratification during the austral summer and aid interpretation of the changes in potential temperature and salinity observed in the sub-ice shelf mooring data.

Preseason laboratory calibrations of the FSI microCTD sensors were done at the Common wealth Scientific and Industrial Research Organization (CSIRO). In the field, data were output from the FSI microCTD with CSIRO calibration coefficients applied for temperature, pressure and conductivity. Prior to deployment, the FSI microCTD was compared against a General Oceanics MarkIII CTD during in situ measurements, and FSI conductivity data were calibrated against the bottle samples obtained. The FSI accuracies were estimated to be: temperature $<0.005^{\circ} \mathrm{C}$, salinity $<0.004$, and pressure $\sim 2$ dbar [9].

Only records that collected in water column beneath AIS are used, and obvious error records such as abnormal bulges and isolated cusps are removed. According to the AM06 mooring diagram and the jump point of CTD profiles from ice borehole to the ocean beneath ice shelf, $524 \mathrm{~m}$ is selected as the upper limit for water column beneath the ice shelf.

\subsection{Subice Shelf Moorings}

At this site, after CTD profiling, a mooring was deployed through the ice shelf into the ocean cavity. The mooring consisted of three Seabird 37IM Microcats and one upward looking RDI $300 \mathrm{kHz}$ broadband Workhorse ADCP (all fixed at different depths) measuring temperature, salinity, pressure and speed at 30 min intervals.

Simultaneous time series oceanographic data were obtained from the mooring string, and details for this string are listed in Table 2. These data are used for the study of circulation and seasonal cycle of the water masses.

Table 1. AM06 GPS coordinates records of each field work season.

\begin{tabular}{ccc}
\hline Date of GPS record & Longitude $\left({ }^{\circ} \mathrm{N}\right)$ & Latitude $\left({ }^{\circ} \mathrm{S}\right)$ \\
\hline $2010-01-01$ & 71.36383 & 70.24583 \\
$2011-01-08$ & 71.36793 & 70.24288 \\
\hline
\end{tabular}

Table 2. Details for borehole AM06 mooring string.

\begin{tabular}{cccc}
\hline \multirow{2}{*}{ Instrument } & \multicolumn{2}{c}{ Instrument position } & Record duration \\
\cline { 2 - 3 } & Depth $(\mathrm{m})$ & Depth (dbar) & 551.4 \\
Microcat 7325 & 545.1 & 680.8 & $2010.1 .7-2011.1 .8$ \\
Microcat 7324 & 672.8 & 790.3 & 642.6 \\
Microcat 7323 & 780.8 & 635.1 & \\
RDI ADCP & 6 & \\
\hline
\end{tabular}


Manufacturer supplied calibrations were applied to the Microcats. The initial accuracy of SBE37IM is: temperature $<0.002^{\circ} \mathrm{C}$, conductivity $<0.0003$, and pressure $\sim 1 \mathrm{dbar}$. The raw files were manually edited to remove data where the Microcats were being deployed. A brief comparison was made between borehole Microcat and CTD temperature and salinity data.

As the ADCP was set upward looking, 27 bins, $4 \mathrm{~m}$ bin length, and the first bin at $6.09 \mathrm{~m}$ from transducers (635.1 $\mathrm{m}$ in depth), the range of ADCP velocity profile is about $100 \mathrm{~m}$ from the bottom of AIS.

According to the GPS records, the local magnetic declination for the years of data measurement at AM06 was about 75.97 (calculated using the program geomag70 downloaded from the NOAA website

www.ngdc.noaa.gov). Local magnetic declination correction-76 was set to be heading bias to reach right velocity direction before deploying.

With bottom tracking and strictly quality controlling applied to the data, such as percent good of 4 beam $\geq 80 \%$, average beam correlation $\geq 70 \%$, bins $27,26,25,24$ and 23 all flagged as bad, bin $21,2019,18,17$ have a lot of invalid data in first 4 months, magnitude and direction component at bin 1 - 16 are selected and averaged for the velocity in range about $100 \mathrm{~m}$ under AIS.

\section{Results}

\subsection{Variability of Temperature and Salinity}

Water masses are classified according to their temperature and salinity values, which retain an imprint of the processes that have modified them. Ice Shelf Water (ISW) has a temperature below the surface freezing point and can be formed when the ambient ocean drives melting at the base of an ice shelf at typically several hundred meters depth, and its temperature might be exceeded by the in situ freezing point [9]. HSSW is a by-product of sea-ice formation and is the densest water mass on the Antarctic continental shelf. It has a temperature at, or close to, the surface freezing point and a wide range of salinity values [2]. As ISW and HSSW are usually the two main water masses at boreholes of AIS, to distinguish ISW and HSSW, here we take $\theta<-2.0^{\circ} \mathrm{C}$ as the ISW's definition, and S > 34.5 as the HSSW's definition.

According to time series of $\theta$ and S from three Seabird 37IM Microcats (Figure 1), ISW and HSSW are the two water masses observed at AM06 throughout the observed period. And from the point of water volume, ISW is the dominant water mass.

Different from those at AM01, the variation trend of $\theta$ and $\mathrm{S}$ at three layers is not consistent and synchronous. If we take the change of $\theta$ at the bottom layer as the leading, according to the two significant features defined by Herraiz-Borreguero et al. [9], another three periods can be distinguished at AM06, which we refer to as the Quiescent Period, the Down Transitional Period and the Rise Transitional Period. These periods are selected to define the main features observed in the whole observed period.

\subsubsection{Quiescent Period (Jan. to Jun., Nov. to Next Jan.)}

There are two sections in this period and two features define this period. The first feature is observed $\theta$ at bottom depths. Within $32 \mathrm{~m}$ above the sea floor, the observed HSSW keeps its potential temperature at about $-1.95^{\circ} \mathrm{C}$, which is higher than the demarcation temperature of HSSW and ISW (Figure 1, green dashed lines), with a sustained slowly decreasing salinity. In addition, although the variability of $\theta$ is very small, the salinity decreased 0.06 in 5 months. Indeed, the summer CTD profiles show that the deepest Microcat moored at AM06 was embedded in the lower mixed layer (Figure 2), so the low variability of $\theta$ at this shallow layer is expected. The second feature is the warming and freshening trend at intermediate and top depths (Figure 1, blue and red). At intermediate depth, a larger swing characteristic of $\theta$ emerges in the later half, and the maximum amplitude is about $0.1^{\circ} \mathrm{C}$.

\subsubsection{Down Transitional Period (Jun. to Sep. 2010)}

This period begins from that $\theta$ decreased below the potential freezing temperature totally at intermediate depth, and the first significant feature of this period is the synchronous cooling and freshening trend at all layers. Another feature of this period is that $\mathrm{S}$ emerges significant perturbation at intermediate and top depths, which is unexpected since these two depths are embedded in the lower mixed layer in the summer CTD profiles (Figure 2). And the perturbation is so outstanding that it has the feature of the Perturbation Period mentioned by HerraizBorreguero at intermediate depth at the same time [9]. At the end of this period, the salinity decreases to 

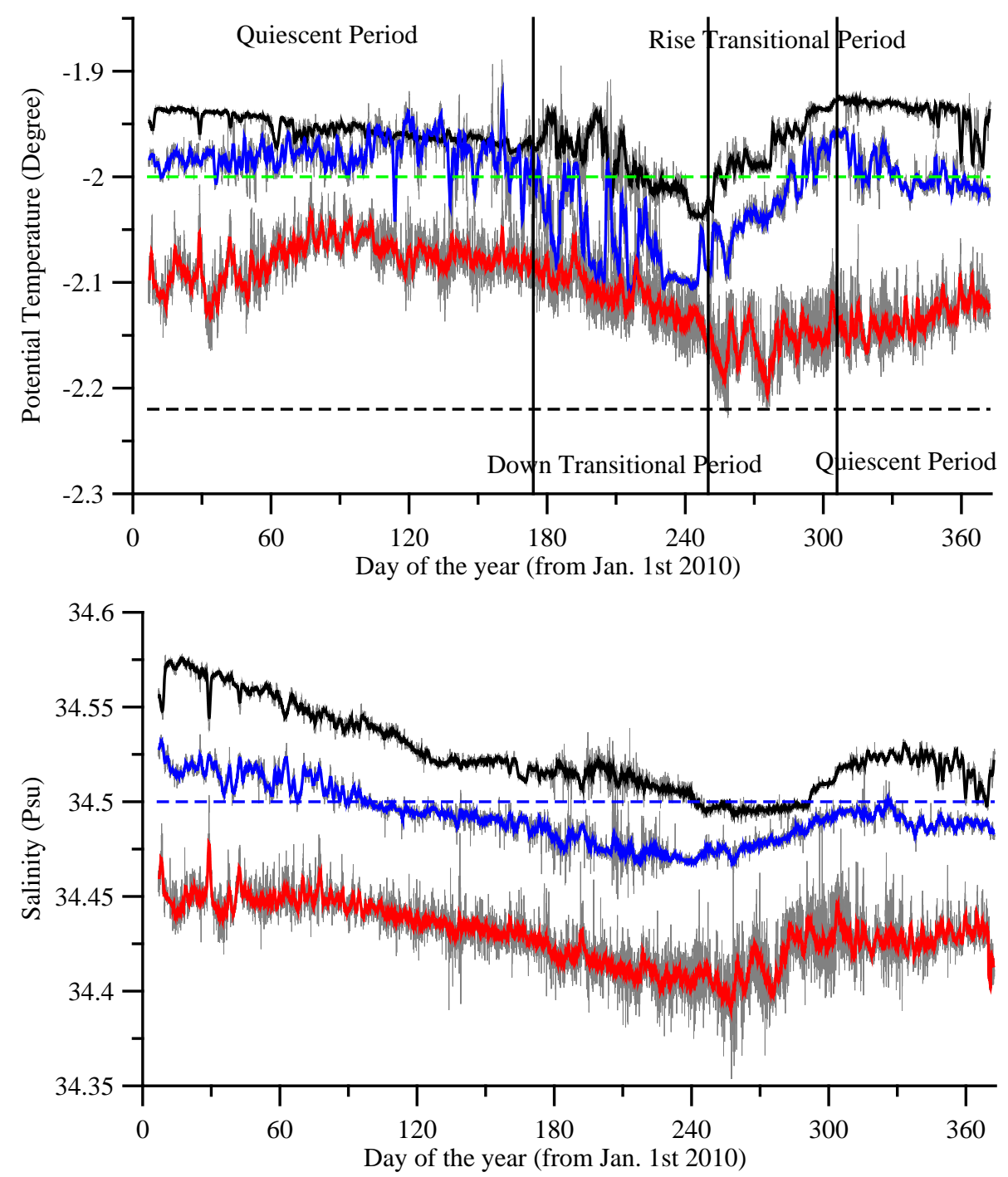

Figure 1. Continuous records of (upper) potential temperature $(\theta)$ and (lower) salinity (T) at AM06 from Jan. $7^{\text {th }} 2010$ to Jan. $8^{\text {th }} 2011$. Each moored Microcat time series is shown in gray with the 25 h filtered time series overlaid. Measurement levels are: top (red, $545.1 \mathrm{~m}$ ), intermediate (blue, $672.8 \mathrm{~m}$ ) and bottom (black, $780.8 \mathrm{~m}$ ). The black dotted line is the potential freezing temperature for the observed salinity at the top level. The green dotted line is the potential temperature upper limit of ISW. The blue dotted line is the salinity lower limit of HSSW.

34.5 at bottom depth, the potential temperature decreases to the freezing point and even keeps to below the freezing point for about a month at intermediate depth.

\subsubsection{Rise Transitional Period (Sep. to Nov.)}

The Rise Transitional Period begins from the end of the Down Transitional Period. The first feature of this period is that S keeps below the HSSW lower limit at bottom depth, which means the shrink of HSSW in all line. An abrupt increase in temperature and a gradual salinity increase mark the arrival of HSSW at intermediate depths at AM06. On the contrary of the Down Transitional Period, another feature of this period is the synchronous warming and salting trend at intermediate and bottom depths. As the shortest period in three periods, $\theta$ at intermediate and bottom depths both recover to their Quiescent Period level at the end of this period, and the absolute change rates of $\theta$ are higher than those of the Down Transitional Period. The perturbation character remains clearly, but now it changes to be at top depth. At the end of this period, $\theta$ at intermediate depth increases to the upper limit of ISW and S at bottom depth increases to the lower limit of HSSW. 

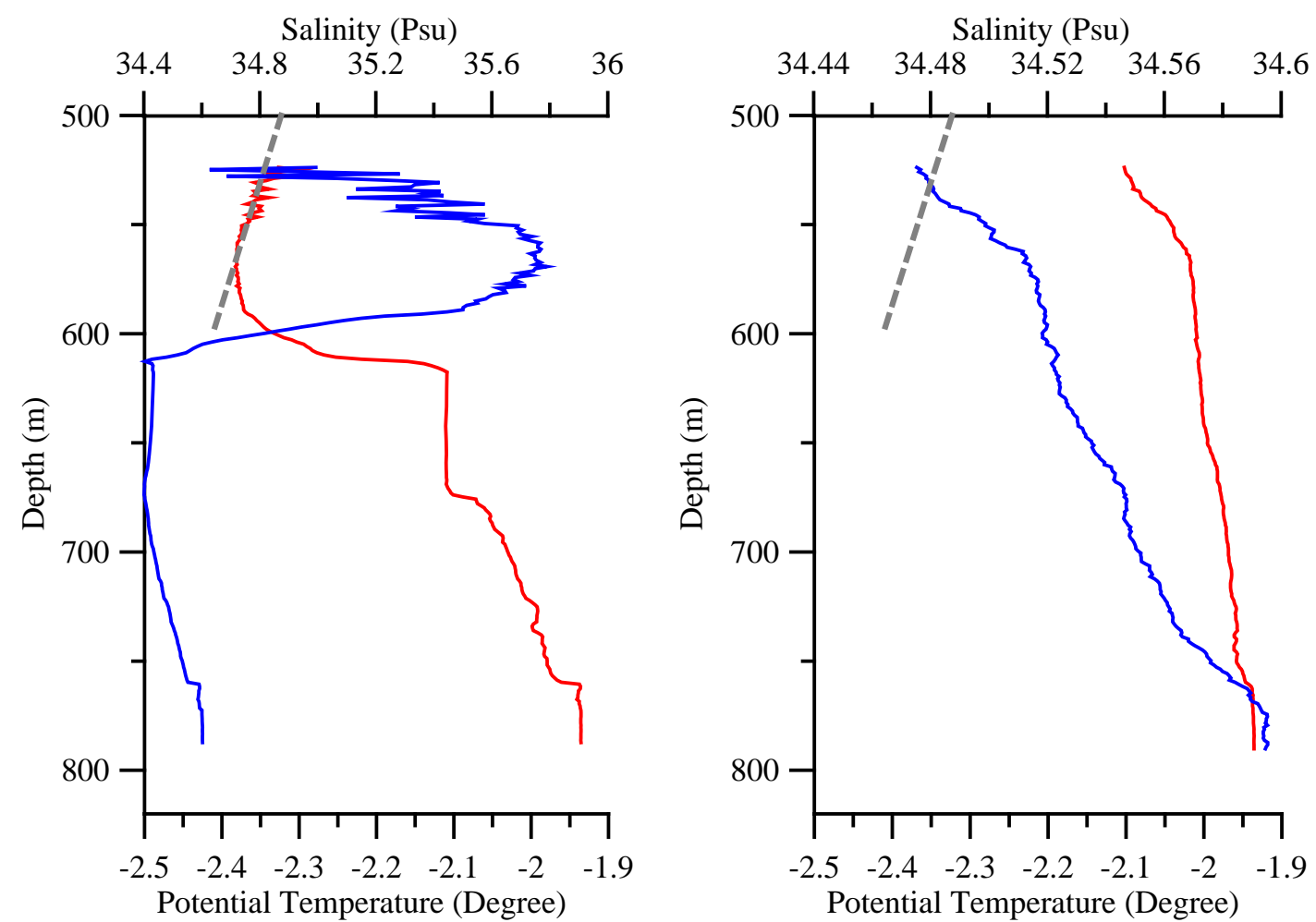

Figure 2. (Left) The first downward and (right) the last upward temperature/salinity profiles at AM06 collected in austral summer. The red line depicts the temperature profile while the blue line depicts the salinity profile. The potential freezing temperature profile, which is adiabatically referenced to the surface, is shown by the grey bold dotted line.

\subsection{The Motion of AIS}

Based on three AM06 coordinates recorded using Garmin GPS in three field work seasons, the speed and direction of AIS surface motion can be calculated in period of 2010-2011 and 2011-2012.

For the first period, from $1^{\text {st }} \mathrm{Jan}$. 2010 to $8^{\text {th }}$ Jan. 2011, the total drift of AM06 is $381.6 \mathrm{~m}$, the displacement in longitude is $195.3 \mathrm{~m}$, while $327.8 \mathrm{~m}$ in latitude. Ignoring the error of Garmin GPS records, and take for granted that the two records time were the same, the drift speed of this site is $1.03 \pm 0.04 \mathrm{~m} \cdot \mathrm{d}^{-1}$, the drift direction is about $30.8^{\circ} \pm 2.3^{\circ}$.

For the second period, from $8^{\text {th }}$ Jan. 2011 to $24^{\text {th }}$ Feb. 2012, the total drift of AM06 is $442.2 \mathrm{~m}$, the displacement in longitude is $242.2 \mathrm{~m}$, while $370.0 \mathrm{~m}$ in latitude. With the same hypothesis as the first period, AM06 drift speed in this period is $1.07 \pm 0.04 \mathrm{~m} \cdot \mathrm{d}^{-1}$ with drift direction about $33.2^{\circ} \pm 1.9^{\circ}$. In this period, the speed is a little faster, the velocity difference is $0.04 \mathrm{~m} \cdot \mathrm{d}^{-1}$, almost the same as the magnitude of error bar.

Zhang et al. has calculated velocity of AIS based on five days GPS records at AM01 during Dec. 2003, their preliminary result showed that the surface ice velocity of AM01 was $2.25 \mathrm{~m} \cdot \mathrm{d}^{-1}$, the motion direction was northeastward $\left(41^{\circ}\right)$ [12]. As AM01 locates at the main streamline of AIS, it is easy to accept the speed of AM06 is less than that of AM01.

Comparing with the surface velocity result of Zhao et al. [15], which was derived from ENVISAT ASAR images, although in the same magnitude level, the drift rate of AM06 is less than the lowest rate of AIS front $\left(1.65 \mathrm{~m} \cdot \mathrm{d}^{-1}\right)$. This agrees with that the closer to the AIS front, the higher expansion rate. As for drift rate is slower during the first period, this also coincides with the result of Zhao et al., as they mentioned that the rates in 2009 and 2010 were generally lower than those in other years [18].

According to the terrestrial traversed velocity of Matt et al. (Figure 3), the drift speed was about $450 \mathrm{~m} \cdot \mathrm{y}^{-1}$ at site nearby AM06 during 1968-1970 [19]. GPS records at AM06 during 2010-2012 confirmed the small significant slowdown, which was observed by Matt $e t a l$. 


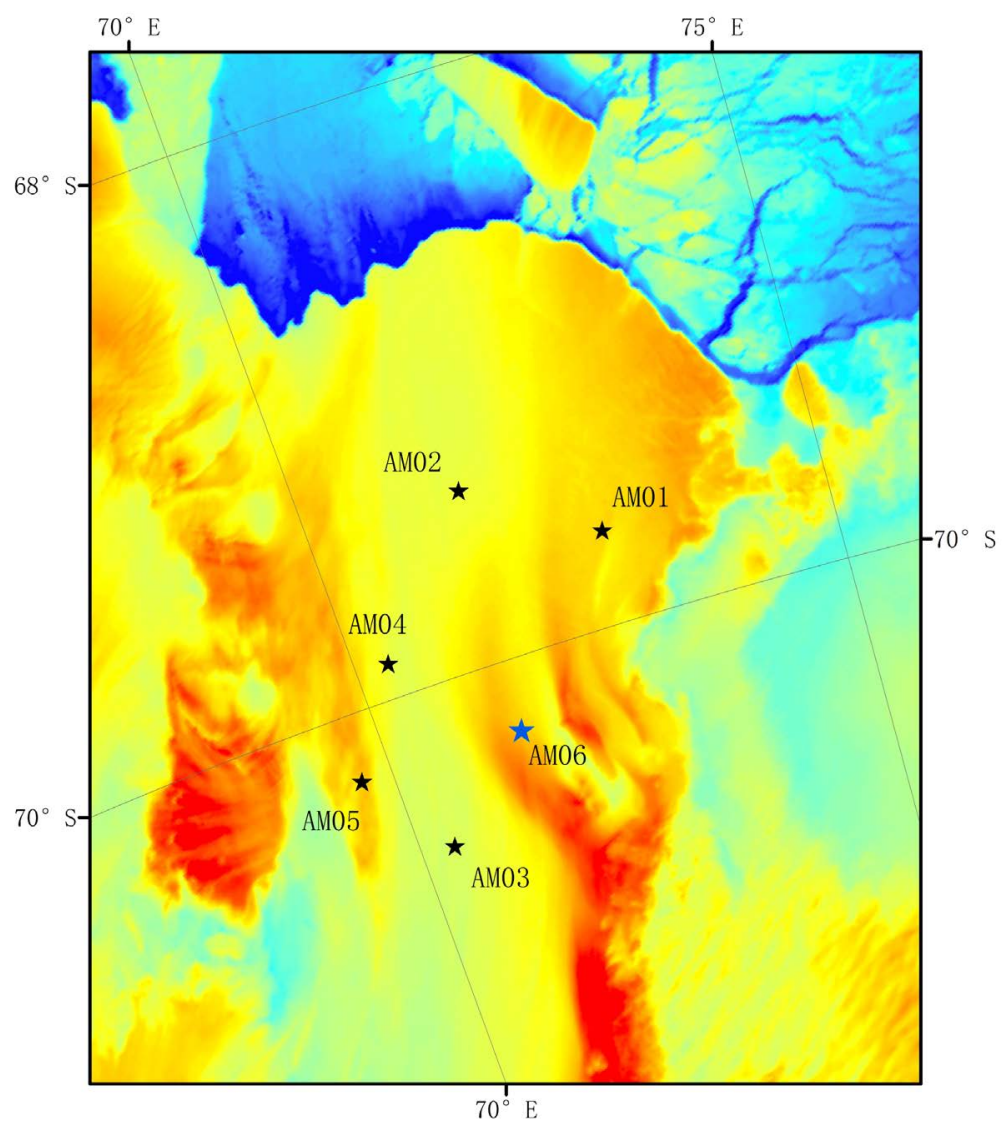

Figure 3. AIS stations map with AM06 highlighted in blue, and the base map is MODIS thermal satellite image (2009) provided by NSIDC.

\subsection{Seasonal Variability of Current}

As the characteristic velocity magnitude recorded by ADCP is about $3 \mathrm{~cm} / \mathrm{s}-5 \mathrm{~cm} / \mathrm{s}$, the velocity of AIS is so small $\left(\sim 1.2 \times 10^{-3} \mathrm{~cm} / \mathrm{s}\right)$ that it can be ignored in ereasing movement of the platform.

Based on the depth of ADCP and parameter setup, bin 1 - 16 of ADCP correspond to the range of $566 \mathrm{~m}$ - 626 $\mathrm{m}$, and the top of the range is about $18 \mathrm{~m}$ below the AIS base. In this range, velocity records are almost consistent (not shown). In order to ignore the daily changes, daily averaged velocity in this range is shown in Figure 4, and rose diagram of flow direction is given in Figure 5. Statistics values for the whole observation period and three distinguished periods are given in Table 3.

In the whole observation period, the maximum velocity is $8.7 \mathrm{~cm} / \mathrm{s}$ with direction about $228.9^{\circ}$, while the minimum velocity is only $0.4 \mathrm{~cm} / \mathrm{s}$ with direction about $53.2^{\circ}$, and the annual mean velocity is $3.3 \mathrm{~cm} / \mathrm{s}$ with direction about $227.5^{\circ}$. From the rose diagram of flow direction, we can see that 83.4 percent of velocity are in the southwest quadrant, and only 16.6 percent are in the other three quadrant. Combined with statistical results, it is clear that the main flow direction is southwest.

The fluctuations of daily averaged velocity magnitude are very obvious, and the typical is in a few days, which are similar to that of Microcat records. The greatest swing occurred in the end of Jan, in three days the velocity decreased more than $7.0 \mathrm{~cm} / \mathrm{s}$. The standard deviation is over $1.4 \mathrm{~cm} / \mathrm{s}$ in the whole observation period.

For synchronization analysis of water masses, here we give the main feature in terms of three periods that distinguished before.

During the Quiescent Period, the velocity is quite larger than other two periods, and the maximum velocity in the whole observation period is also occurs in this period. The mean velocity is $4.0 \mathrm{~cm} / \mathrm{s}$ with direction about $227.5^{\circ}$. Except in a few days the flow is westward or northwestward, the flow is southwestward mostly. During late Apr. to early Jun, the flow is stable relatively, the velocity is around $4 \mathrm{~cm} / \mathrm{s}$ with southwest direction. 

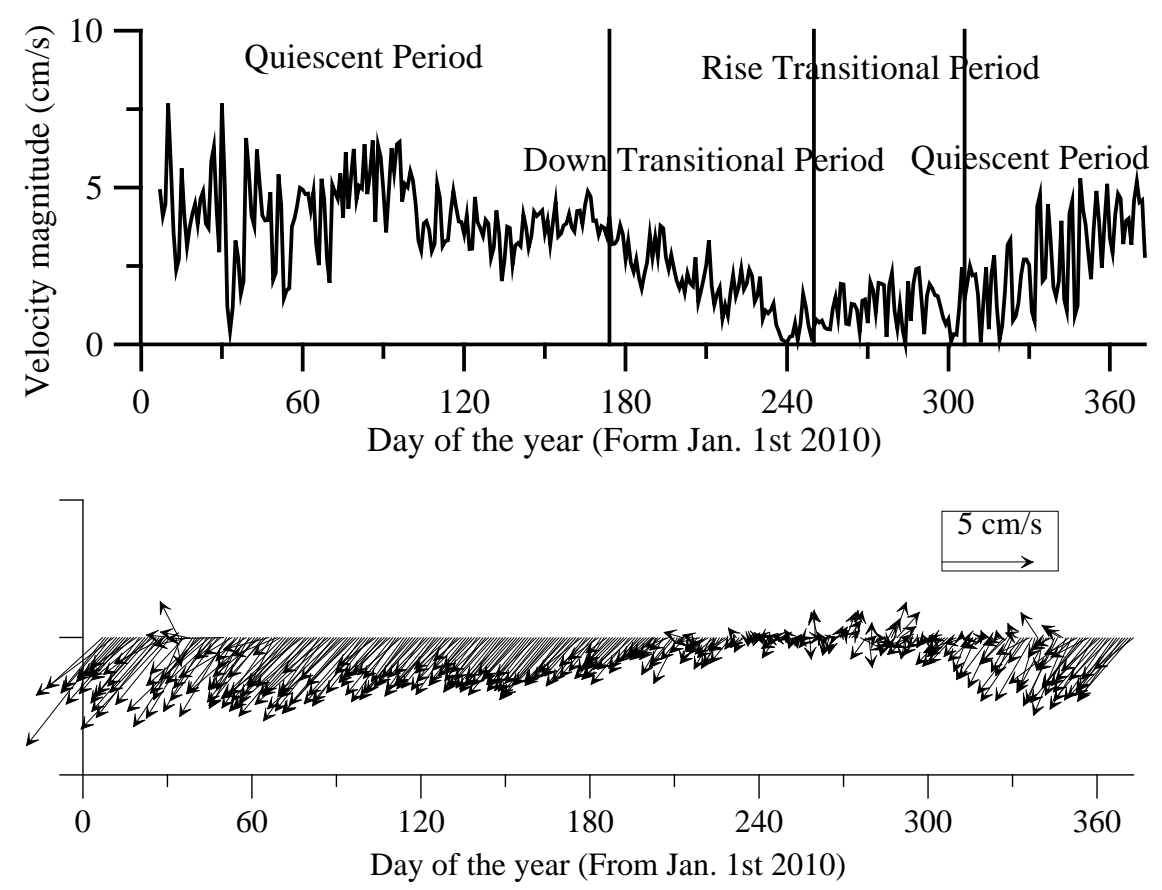

Figure 4. Continuous records of daily averaged ADCP velocity (upper) magnitude and (lower) vector in range of $542 \mathrm{~m}$ $626 \mathrm{~m}$ at AM06 from Jan. $7^{\text {th }} 2010$ to Jan. $8^{\text {th }} 2011$.
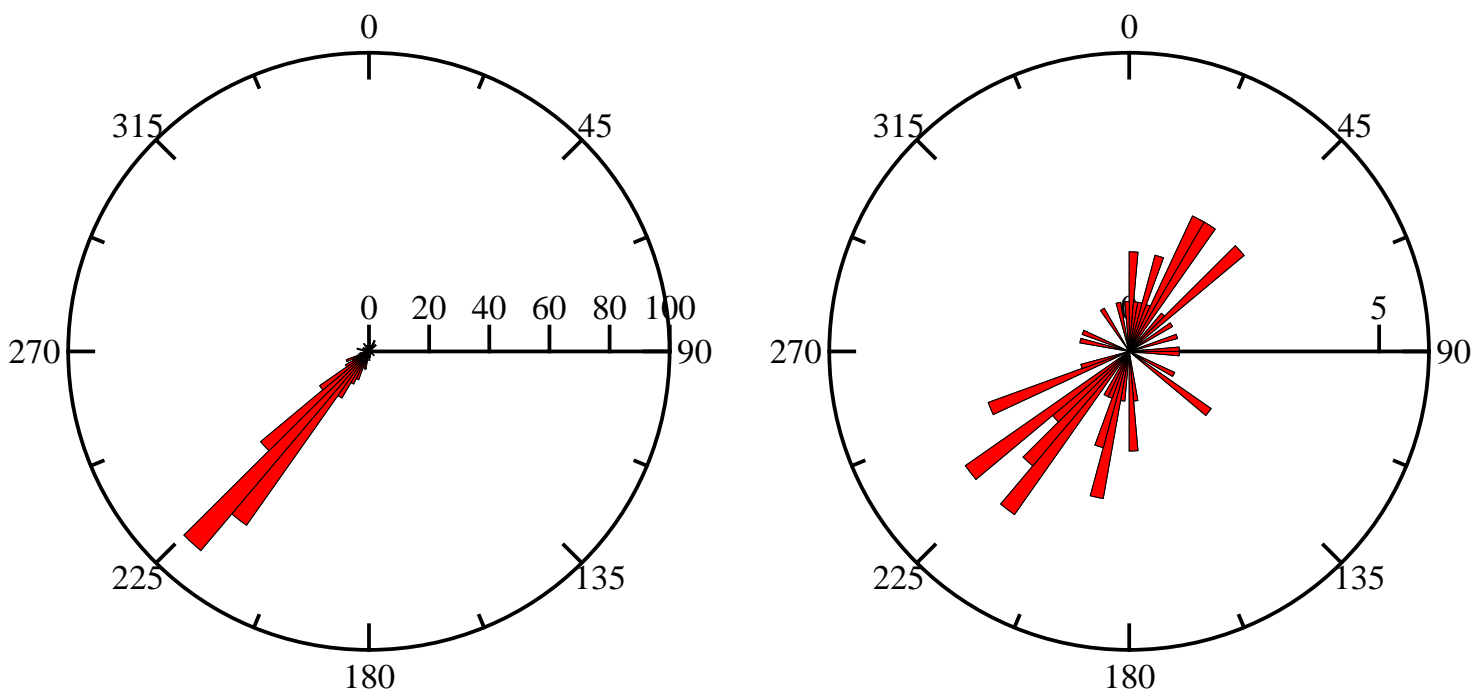

Figure 5. (Right) Whole observation period and (left) rise transitional period rose diagram of daily averaged flow direction with bin size $5^{\circ}$, and radius axis stands for occurrence times of each bin.

Table 3. Statistics table for velocity and corresponding direction in different period.

\begin{tabular}{cccc}
\hline & Mean & Maximum & Minimum \\
\hline Whole period & $3.30 \mathrm{~cm} / \mathrm{s}, 227.5^{\circ}$ & $8.67 \mathrm{~cm} / \mathrm{s}, 228.9^{\circ}$ & $0.42 \mathrm{~cm} / \mathrm{s}, 82.5^{\circ}$ \\
Quiescent period & $4.02 \mathrm{~cm} / \mathrm{s}, 227.5^{\circ}$ & $8.67 \mathrm{~cm} / \mathrm{s}, 228.9^{\circ}$ & $0.67 \mathrm{~cm} / \mathrm{s}, 84.6^{\circ}$ \\
Down transitional period & $2.15 \mathrm{~cm} / \mathrm{s}, 225.8^{\circ}$ & $4.11 \mathrm{~cm} / \mathrm{s}, 227.1^{\circ}$ & $0.64 \mathrm{~cm} / \mathrm{s}, 82.5^{\circ}$ \\
Rise transitional period & $1.39 \mathrm{~cm} / \mathrm{s}, 52.1^{\circ}$ & $2.67 \mathrm{~cm} / \mathrm{s}, 233.2^{\circ}$ & $0.42 \mathrm{~cm} / \mathrm{s}, 53.2^{\circ}$ \\
\hline
\end{tabular}


Although the mean current direction is still southwest in the Down Transitional Period, the mean velocity is only $2.1 \mathrm{~cm} / \mathrm{s}$, only the half of that in the Quiescent Period. In this period, the velocity decreases gradually with several fluctuations, it reaches its minimum velocity $(0.6 \mathrm{~cm} / \mathrm{s})$ and its direction begins to swing significantly at the end of this period.

In the Rise Transitional Period, the current direction varies complex mostly, it even reverses for several times in a few days. Although there is no dominant flow direction in this period, the averaged flow direction is northeast. Both the mean velocity and minimum velocity reaches their minimum in the whole observation period, they are $1.4 \mathrm{~cm} / \mathrm{s}$ with corresponding direction $52.1^{\circ}$, and $0.4 \mathrm{~cm} / \mathrm{s}$ with corresponding direction $47.7^{\circ}$.

\section{Summary and Conclusion}

\subsection{Bottom Regime of AM06}

Only two recorded potential temperatures are below the potential freezing temperature in over 17,500 original records, and no record of the potential temperature is less than the freezing point in the $25 \mathrm{~h}$ filtered time series. This means that at the top depth of subice shelf mooring, which is only $20 \mathrm{~m}$ below the AIS basal, the water is not frozen all year round.

Although there are a few recorded potential temperatures below the potential freezing temperature in upper 40 $\mathrm{m}$ of the first downward CTD profile, which stands for the undisturbed water column state, all $\theta$ records are higher than those of the freezing point in other 9 profiles including the first upward profile. Even more, all $\theta$ records are more than $0.24^{\circ} \mathrm{C}$ at least in the last profile.

As $\theta$ values are totally higher than those of the in situ potential freezing temperature, which is similar to those of AM02, it is difficult to form frazil ice crystals beneath AIS at AM06. This suggests that AM06 locates in the active melt basal regime, and the basal melting of ice shelves happens full year, which is further confirmed by the increasement of ADCP effective observation range in first several months.

\subsection{Circulation and Variability of Water}

The annual records of ADCP and Micracats at AM06 are used to infer the most likely circulation pattern beneath the AIS. Except very few records, all the evidence suggests that there are only two kinds of water masses under AIS in 2010, they are ISW and HSSW. Usually ISW lies in the upper layer of the water column, while HSSW locates in the lower layer.

Combining Figure 1 and Figure 4, it is easy to see that the southwest flow decreases with the temperature decreasing, which means the external water that flows in has a higher temperature, and the local effect is cooling. While the synchronization of southwest flow decreasing and salinity decreasing means that the external water is saltier, and the local effect is fresh. All these mean that the external water might be HSSW, and the basal melting occurs on glacial ice.

In most time of Quiescent Period, the circulation at AM06 is a directional flow, with fixed direction of southwestward, and the mean velocity is $4.0 \mathrm{~cm} / \mathrm{s}$ in range of $566 \mathrm{~m}-626 \mathrm{~m}$. As the current profiles are consistent in different observation levels (not shown), together with the relative constant variation during this period, it can be inferred that almost the whole water at AM06 is in a southwest flow (the upper and bottom boundary layers are excluded since the friction effects).

When the southwestward flow is relatively strong ( $\geq 5 \mathrm{~cm} / \mathrm{s}$ ), the HSSW inflows into the cavity from outside, and most part of the water column is filled up with HSSW below the intermediate depths. In this condition, as $\theta$ beneath the ice shelf is higher than the potential freezing point, the circulation driven by the inflow of continental shelf water dominates the whole water column, which causes ice shelf basal melt, and also can potentially contribute to the formation of ISW. Now the intermediate depth is roughly the interface of HSSW and ISW. If we take $524 \mathrm{~m}-813 \mathrm{~m}$ as the full water column range, HSSW occupies more than 50 percent of the full water column in average, and ISW occupies the rest proportion.

When the flow is relatively weak ( $<3 \mathrm{~cm} / \mathrm{s}$ ) in Quiescent Period, and the flow decreases more weakly during Down Transitional Period, although it is still southwestward flow now, an abrupt decrease in temperature and a more gradual salinity decrease mark the shrink of HSSW. Accompanied by the inflow slowing down into the cavity, ISW begins to sink down and flow out, a gradual decrease in temperature and salinity occurs at both intermediate and bottom depths, the thickness of HSSW becomes thin gradually until it disappears, ISW that formed in upper layers begins to fill up the cavity. The full water column keeps being ISW for about a month 
during the transition from Down Transitional Period to Rise Transitional Period.

When the flow direction is without fixed direction and velocity is quite small during Rise Transitional Period, the inflow of HSSW alternates with the outflow of ISW, HSSW and ISW mix together in range of the intermediate and top depths, and the percentage of ISW decreases gradually to be over $50 \%$.

In austral summer of 2011, although the flow returned to steady southwestward and the velocity increased over $4 \mathrm{~cm} / \mathrm{s}$, the water property did not return to the status of austral summer of 2010, which showed up the interannual variation character and remnant memory of last year. If we take vertical linear transition of the water property for granted, ISW is the main water mass and occupies more that 60 percent of the whole water column in the second part of Quiescent Period, while both HSSW and the mixture water occupy about $20 \%$ respectively now.

\section{Acknowledgements}

This study is supported by Public Science And Technology Research Funds Projects of Ocean (No. 201405031), the National High Technology Research And Development Program (No. 2011AA090401), the Polar Strategic Funds Key Project (20150102) and the National Basic Research Program of China (973 Program) (No. 2010CB950301). The physical oceanography data of CHINARE-26 are provided by the Antarctic and Arctic Data Center of China, while data of AM06 are provided by the Australian Antarctic Data Center.

\section{References}

[1] Smith, N., Dong, Z.Q., Kerry, K. and Wright, S. (1984) Water Masses and Circulation in the Region of Prydz Bay, Antarctica. Deep Sea Research Part A. Oceanographic Research Papers, 31, 1121-1147. http://dx.doi.org/10.1016/0198-0149(84)90016-5

[2] Whitworth, T., Orsi, A., Kim, S., et al. (1998) Water Masses and Mixing near the Antarctic Slope Front. Antarctic Research Series, 75, 1-27. http://dx.doi.org/10.1029/AR075p0001

[3] Wong, A., Bindoff, N. and Forbes, A. (1998) On Bottom Water Formation and Ocean-Ice Shelf Interaction in Prydz Bay, Antarctica. In Jacobs, S.S. and Weiss, R.F., Eds., Ocean, Ice and Atmosphere: Interactions at the Antarctic Continental Margin, Vol. 75, American Geophysical Union, Washington DC, 173-185.

[4] Church, J., Bindoff, N., Hunter, J., et al. (2002) Why Are We So Interested in the Amery Ice Shelf? Australian Antarctic Magazine, 3, 1-2.

[5] Allison, I. (2003) The AMISOR Project: Ice Shelf Dynamics and Ice-Ocean Interaction of the Amery Ice Shelf. FRISP Report, 14, 1-9.

[6] Rosenberg, M., Bindoff, N., Curran, C., et al. (2002) Amery Ice Shelf Experiment (AMISOR), Marine Science Cruises AU0106 and AU0207-Oceanographic Field Measurements and Analysis. Antarctic Cooperative Research Centre Research Report, 30, 119.

[7] Craven, M., Allison, I., Brand, R., et al. (2004) Initial Borehole Results from the Amery Ice Shelf Hot-Water Drilling Project. Annals of Glaciology, 39, 531-539. http://dx.doi.org/10.3189/172756404781814311

[8] Craven, M., Allison, I., Fricker, H. and Warner, R. (2009) Properties of a Marine Ice Layer under the Amery Ice Shelf, East Antarctica. Journal of Glaciology, 55, 717-728. http://dx.doi.org/10.3189/002214309789470941

[9] Herraiz-Borreguero, L., Allison, I., Craven, M., Nicholls, K.W. and Rosenberg, M.A. (2013) Ice Shelf/Ocean Interactions under the Amery Ice Shelf: Seasonal Variability and Its Effect on Marine Ice Formation. Journal of Geophysical Research: Oceans, 118, 7117-7131. http://dx.doi.org/10.1002/2013JC009158

[10] Herraiz-Borreguero, L., Coleman, R., Allison, I., Rintoul, S.R., Craven, M. and Williams, G.D. (2015) Circulation of Modified Circumpolar Deep Water and Basal Melt beneath the Amery Ice Shelf, East Antarctica. Journal of Geophysical Research: Oceans, 120, 3098-3112. http://dx.doi.org/10.1002/2015jc010697

[11] Deng, S.K. and Sun, B. (2004) Ice-Surface Based Radar Detection Revealed the Basic Internal Structure Characteristics of Amery Ece Shelf, East Antarctic. Chinese Journal of Engineering Geophysics, 1, 1-9.

[12] Zhang, X.H. and Er, D.C. (2005) Dynamic Parameters Determination of Amery Ice Shelf Using PPP. Geomatics and Information Science of Wuhan University, 30, 909-912.

[13] Zhang, S.K., Er, D.C., Li, F., et al. (2009) The Tidal Signals Extracted from GPS Data on the Amery Ice Shelf, Antarctica. Journal of Glaciology and Geocryology, 31, 1156-1160.

[14] Chen, H.X., Pan, Z.D., Jiao, Y.T., et al. (2005) Hydrological Character and Sea Current Structure in the Front of Amery Ice Shelf. Chinese Journal of Polar Research, 17, 139-148. 
[15] Wen, J.H., Wang, Y.F., Wang, W.L., Jezek, K.C., Liu, H.X. and Allison, I. (2010) Basal Melting and Freezing under the Amery Ice Shelf, East Antarctica, Journal of Glaciology, 56, 81-90. http://dx.doi.org/10.3189/002214310791190820

[16] Fricker, H., Popov, S., Allison, I., et al. (2001) Distribution of Marine Ice beneath the Amery Ice Shelf. Geophysical Research Letters, 28, 2241-2244. http://dx.doi.org/10.1029/2000GL012461

[17] Williams, M., Grosfeld, K., Warner, R. and Young, N. (2001) Ocean Circulation and Ice-Ocean Interaction beneath the Amery Ice Shelf, Antarctica. Journal of Geophysical Research, 106, 22,383-22,399. http://dx.doi.org/10.1029/2000JC000236

[18] Zhao, C., Cheng, X., Hui, F.M., et al. (2013) Monitoring the Amery Ice Shelf front during 2004-2012 Using ENVISAT ASAR Data. Advances in Polar Science, 24, 133-137. http://dx.doi.org/10.3724/SP.J.1085.2013.00133

[19] King, M.A., Coleman, R., Morgan, P.J. and Hurd, R.S. (2007) Velocity Change of the Amery Ice Shelf, East Antarctica, during the Period 1968-1999. Journal of Geophysical Research, 112, F01013.

http://dx.doi.org/10.1029/2006JF000609 